\title{
Genetics of Type 2 Diabetes: Impact of Interleukin-6 Gene Variants
}

\section{Genetik von Typ-2-Diabetes: Einfluss von Interleukin-6-Genvarianten}

\section{T. Illig ${ }^{1}$}

F. Bongardt ${ }^{1}$

A. Schöpfer-Wendels ${ }^{1}$

C. Huth ${ }^{1}$

I. Heid ${ }^{1}$

W. Rathmann ${ }^{2}$

S. Martin ${ }^{3}$

C. Vollmert ${ }^{1}$

R. Holle

B. Thorand ${ }^{1}$

H. EWichmann ${ }^{1}$

W. Koenig ${ }^{5}$

H. Kolb ${ }^{3}$

C. Herder ${ }^{3}$

for the KORA Study Group*

\section{Zusammenfassung}

Die KORA-Studien bieten eine hervorragende Basis, um komplexe Erkrankungen wie Typ-2-Diabetes oder das metabolische Syndrom auf genetischer Ebene zu analysieren. In diesen Studien wurden mehr als 2000 Typ-2-Diabetiker identifiziert, von denen DNA für genetische Analysen zur Verfügung steht. Bisher stand die Analyse von Genen im Vordergrund, die an der Inflammationsantwort beteiligt sind. Interleukin-6 (IL-6) als zentraler Mediator der Akutphase-Reaktion ist von Interesse. Erhöhte IL6-Proteinkonzentrationen im Blut können die Entstehung von Typ-2-Diabetes vorhersagen. Da der Einfluss einer DNA-Variante im Promotor des Interleukin-6-Gens bisher nicht in einer populationsbasierten Studie untersucht wurde, analysierten wir die Assoziation des Einzelnukleotidbasenaustausches (SNPs) C-174G in einer Fall-Kontroll-Studie mit 704 älteren Probanden des KORA-Surveys S4 (1999/2001). Das Allel - 174G zeigte eine Tendenz zur Assoziation mit Typ-2-Diabetes (-174G: OR 1,20, 95\%-KI $0,90-1,59, \mathrm{p}=0,21$ ).

\section{Schlüsselwörter}

Biologische Materialien · genetische Epidemiologie $\cdot$ MONICA/ KORA $\cdot$ Typ-2-Diabetes $\cdot$ metabolisches Syndrom

\section{Abstract}

The KORA studies serve as a powerful tool for the genetic analysis of complex diseases like type 2 diabetes or the metabolic syndrome. These studies include more than 2,000 prevalent and incident type 2 diabetes cases. DNA of these patients is available to be used in genetic studies. Up to now the analyses have focussed on genes coding for proteins being involved in the inflammatory response. Interleukin-6 (IL-6) as the key mediator of the acute phase reaction is of interest. Elevated protein concentrations of IL-6 in the blood have been shown to predict type 2 diabetes. We investigated the association of the IL-6 single nucleotide polymorphism (SNP) C-174G with type 2 diabetes in a case-control study of 704 elderly participants of the KORA Survey S4 (1999/2001).

When BMI, HDL cholesterol, physical activity, hypertension, hormone replacement therapy and smoking were considered as covariables the SNP C-174G showed a trend for association with type 2 diabetes (-174G: OR 1.20, 95\% CI 0.90-1.59, $\mathrm{p}=0.21$ ).

\section{Key words}

Biological materials - genetic epidemiology - MONICA/KORA . type 2 diabetes

note

* The KORA study group consists of H.-E. Wichmann (speaker), H. Löwel, C. Meisinger, T. Illig, R. Holle, J. John and co-workers who are responsible for the design and conduct of the KORA studies.

\section{affiliation}

${ }^{1}$ GSF National Research Center for Environment and Health, Institute of Epidemiology, Neuherberg, Germany

${ }^{2}$ Leibniz Institute at the Heinrich-Heine-University, Institute of Biometrics and Epidemiology, German Diabetes Center, Düsseldorf, Germany

${ }^{3}$ Leibniz Institute at the Heinrich-Heine-University, German Diabetes Clinic, German Diabetes Center, Düsseldorf, Germany

${ }^{4}$ GSF National Research Center for Environment and Health, Institute of Health Economics and Health Care Management, Neuherberg, Germany

${ }^{5}$ University of Ulm, Medical Centre, Department Internal Medicine II-Cardiology, Ulm, Germany

correspondence

Dr. Thomas Illig - GSF National Research Center for Environment and Health, Institute of Epidemiology · Ingolstaedter Landstraße 1·85764 Neuherberg · Germany·E-mail: illig@gsf.de

bibliography

Gesundheitswesen 2005; 67 Sonderheft 1: S122 -S126 @ Georg Thieme Verlag KG Stuttgart · New York DOI $10.1055 / \mathrm{s}-2005-858396$

ISSN 0949-7013 
Description of KORA cohorts and additional infrastructure available for genetic research

One major focus of the KORA studies is the genetic analysis of type 2 diabetes (T2D), which is a quite common disease in adults [1]. Therefore the population-based MONICA/KORA surveys ( 1 1S4) offer a powerful source for the genetic analysis of T2D. DNA of more than 700 prevalent type 2 diabetes patients is available in all four surveys. Moreover, follow-up studies performed in MONICA/KORA S1-S3 yielded more than 500 incident cases having developed the disease after their first visit at the KORA study center. These are of special value as we can perform prospective analyses, based on their risk profile at the baseline-investigation. Of special interest for genetic analyses on type 2 diabetes, a subpopulation of the KORA Survey S4 (1999/2001) consisting of subjects in the age range of 55-74 years was chosen to investigate this issue. In this age range 1,653 persons participated in a standardized interview followed by intensive biochemical and clinical analyses. Our cooperation partners performed the main biochemical and immunological analyses (Dr. Kolb, Dr. Herder DDZ, Düsseldorf; Dr. Koenig, University, Ulm). Moreover, an oral glucose tolerance test (OGTT) (Dr. Rathmann DDZ, Düsseldorf) was carried out in this age group. For a case-control study a total of 230 individuals with T2D and 235 individuals with impaired glucose tolerance (IGT) were selected. 239 normoglycemic controls were randomly selected after frequency matching for age and sex. Of the diabetic patients, 120 were newly detected by OGTT and did not yet receive anti-diabetic treatment. In these 704 probands a number of additional biochemical markers were determined. For example, serum concentrations of more than 40 inflammatory proteins (adhesion molecules, acute phase proteins, interleukins and their receptors, chemokines and their receptors) were measured.

Additionally, a family study including 600 families focussing specifically on T2D was recruited in 2001/2002.

From most of the subjects of the described studies genomic DNA as well as plasma/serum samples are available. In KORA S4 immortalized Epstein-Barr-Virus cell lines have been generated from 1,600 subjects serving as a backup for genomic DNA and for functional studies to investigate the relevance of certain DNA variants concerning the aetiology of T2D. Therefore the KORA platform offers a promising source for molecular T2D studies. Moreover, the GSF - National Research Centre for Environment and Health has established a high throughput genotyping MALDI TOF MS based platform (Sequenom, San Diego, USA), which is mainly run by the Institutes of Epidemiology and Human Genetics.

\section{Association results of polymorphisms in the IL-6 gene with type 2 diabetes in a subpopulation of KORA S4}

In recent years, evidence has accumulated that type 2 diabetes is associated with a subclinical systemic inflammation which might be attributable to an impaired regulation of the innate immune system. Therefore, a special interest has been laid on the effect of genes coding for proteins involved in the inflammatory answer to further elucidate this pathway.
In this review the results of the IL- 6 candidate gene, which was analyzed in the above mentioned subgroup of 704 individuals aged 55-74 years (230 type 2 diabetes patients, 235 patients with IGT and 239 controls frequency-matched for age and sex subjects) will be presented in detail [2].

\section{Basic characteristics of groups studied}

Table 1 shows the association of diabetes status with parameters of the metabolic syndrome and with inflammatory markers. As age and sex were matching variables no difference was seen, whereas mean or median values of the metabolic parameters differed between type 2 diabetic patients and non diabetic control subjects. Individuals with IGT showed statistically significant differences in BMI, insulin resistence, fasting insulin and fasting triglyceride concentrations compared to nondiabetic control subjects. The group with type 2 diabetes or IGT exhibited characteristics of subclinical inflammation, with elevated systemic levels of leucocytes, IL-6, C-reactive protein (CRP), serum amyloid A (SAA) or fibrinogen. Fibrinogen was only significant comparing type 2 diabetes patients with healthy controls.

\section{Association results between IL-6 polymorphisms and type 2 diabetes}

Conditional logistic regression yielded an odds ratio (OR) of 1.17 (95\% CI $0.92-1.50, \mathrm{p}=0.21)$ with no covariables included. When BMI, HDL cholesterol, physical activity, hypertension, hormone replacement therapy and smoking were considered as covariables the OR was 1.20 (95\% CI $0.90-1.59$, p = 0.21).

\section{Discussion}

It has been shown previously that elevated levels of IL-6 are not only associated with T2D, but also with IGT and predict the development of the disease $[3,4]$ indicating a potential role of this cytokine in the aetiology of type 2 diabetes. Therefore, it seemed possible that single nucleotide polymorphisms (SNPs) in the IL-6 gene $[5,6]$ might be considered as risk factors for the development of type 2 diabetes. Recent studies reported conflicting results about an association between the $\mathrm{C}-174 \mathrm{G}$ polymorphism in the IL-6 promoter region with type 2 diabetes or insulin resistance [7-12]. Whereas analyses of Native American, British and Spanish individuals found the G allele of the C-174G SNP to be associated with higher risk of type 2 diabetes [11, 12], this SNP has been reported not to be linked with diabetes in the course of the Finnish Diabetes Prevention Study (DPS) [8]. Furthermore, one small study with non-diabetic subjects described an association of the $-174 \mathrm{C} / \mathrm{C}$ genotype with the related trait of higher insulin sensitivity [7], whereas a different study in normoglycemic individuals came to the opposite result [9]. The comparison of these studies is hampered by the fact that study groups differed in age, degree of obesity, glucose tolerance and sex distribution.

Therefore, we re-evaluated the relevance of one IL-6 SNP for type 2 diabetes on the basis of the KORA S4. We extended our analysis by testing for influences of sex, and BMI and for impact on parameters of the metabolic syndrome and subclinical systemic inflammation (Table 1). Subclinical inflammation might reveal a potential mediator that links the IL-6 SNPs with diabetes. 
Our results support the association of the C-174G SNP with diabetes as shown in two studies $[11,12]$. We were not able to demonstrate an association of the SNPs with insulin resistance and impaired glucose tolerance, which precede the development of overt type 2 diabetes. It can be assumed that diabetes-related factors, in particular BMI, but also hypertension or cholesterol levels may interact with the IL-6 SNPs and modulate their impact on diabetes. Since adipocytes secrete IL-6 in vivo and systemic IL-6 levels are augmented in obesity [13], the SNP-mediated impact on IL-6 expression might depend on the degree of obesity. In the study of Möhlig et al. the C-174G polymorphism affected the correlation between BMI and IL-6 levels [10]. Moreover, it has been shown that the regulatory effect of the different SNPs within the IL- 6 promoter on IL- 6 expression is cell-type specific. The production of IL- 6 by adipocytes may be affected differently by genetic polymorphisms in the promoter region compared to other cell types. The view that as yet undefined parameters can enhance or suppress the impact of SNPs on IL-6 levels is supported by the observation that the $-573 \mathrm{C}$ allele was found to be associated with significantly augmented IL-6 peak levels after coronary artery bypass graft surgery whereas regarding the baseline IL-6 levels, no difference between the $-573 \mathrm{G} / \mathrm{G}$ and - 573C/G genotypes could be detected before surgery [14].

Immune gene polymorphisms may be considered as risk factors only in certain population segments. Consequentially comprehensive studies with a high number of participants may indeed be required to detect SNP-related increased risks in these groups, whereas smaller studies might include patient selection-inherent biases that can skew the outcome and do not reflect the general risk of a population. Therefore a large meta-analysis regarding the association between type 2 diabetes and variants in the interleukin 6 gene is coordinated at the moment by the GSF Institute of Epidemiology.

Table 1 Case-Control Study population of KORA Survey S4 (1999/2001): Association of type 2 diabetes status with components of the metabolic syndrome and subclinical inflammation. For the variables waist circumference, BMI, LDL cholesterol, HDL cholesterol, total cholesterol, leukocyte count and age, means \pm SD are shown. The respective $p$-values result from analysis of variance (ANOVA). The median and the interquartile range are shown for markers of subclinical inflammation (IL-6, CRP, SAA, fibrinogen, MCP-1/CCL2) and for HOMA-insulin resistance, insulin and fasting triglycerides. The respective p-values were obtained with the non-parametric Kruskal-Wallis test. Frequencies of male and female probands are given with a $p$-value resulting from conditional logistic regression. The groups were adjusted for age and sex. Only data from subjects which were both genotyped and phenotyped are given [2].

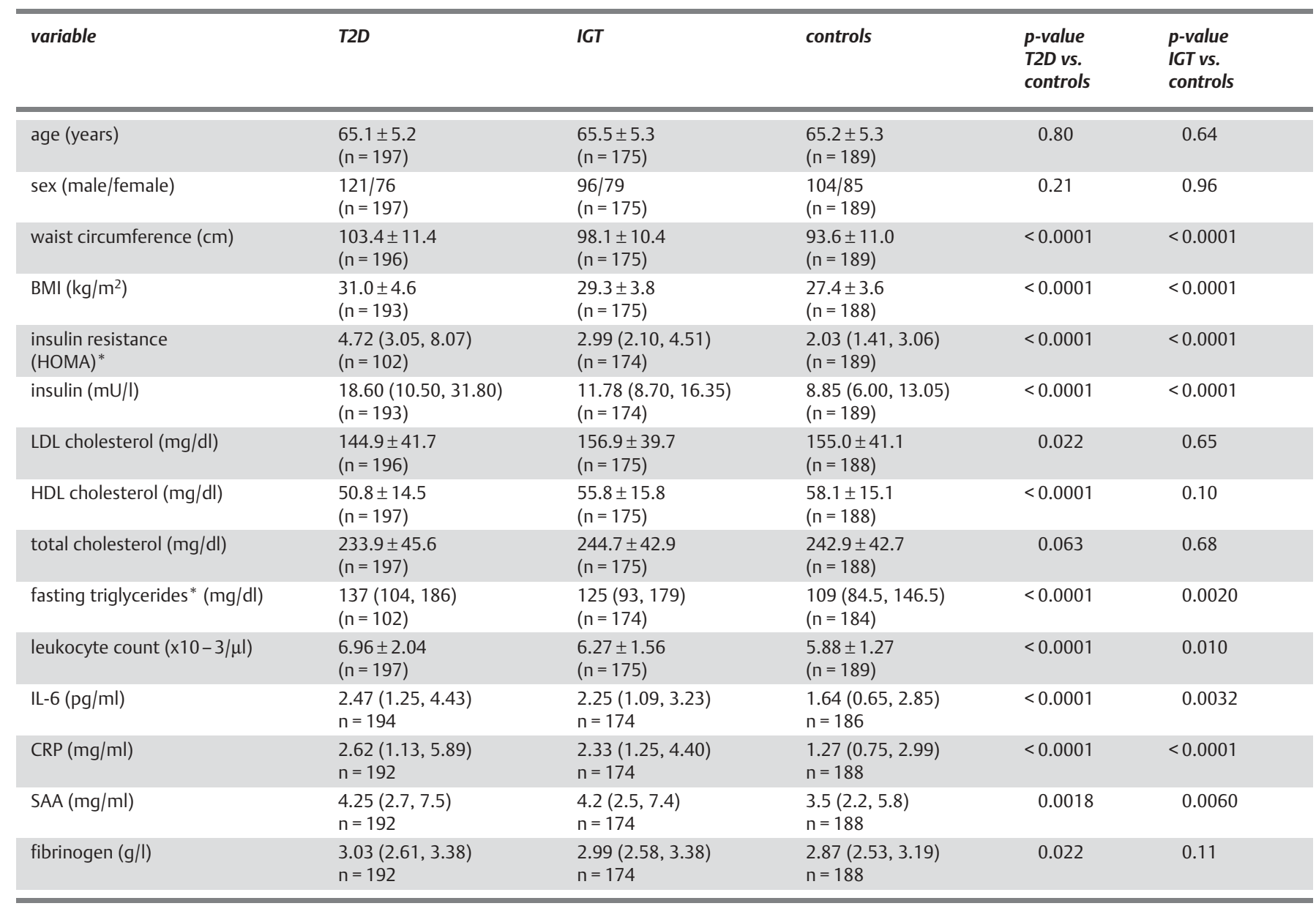

* Patients with a history of diabetes provided non-fasting blood samples and were excluded.

IGT = impaired glucose tolerance; T2D = type 2 diabetes 
The article refers specifically to the following contributions of

Based on data from the different KORA studies it is possible to perform powerful genetic studies on type 2 diabetes. As the KORA subjects are extremely well phenotyped, the analyses can be adjusted properly for putative confounders and analysed for gene-environment interactions. Since 2002 these studies are running at the GSF [2,15-17] and the genetic work within the KORA studies will be strengthened in the future years. More than 700 prevalent T2D cases and more than 3,000 age and sex matched controls as well as 600 families with at least one type 2 diabetic individual per family have been recruited in the last 20 years. Additionally, more than 500 incident cases of type 2 diabetes occurred in the course of the MONICA/KORA follow-up studies. All of these are now available for genetic analyses. Further follow-up studies are conducted at the moment and planned for the future.

This comprehensive population resource offers an optimal possibility to analyse and validate the genetic association between candidate genes and the disease, including effect modification through environmental factors and gene-gene-interactions, to better understand the aetiology of T2D. These analyses could become an important tool for better prevention and medication strategies in the future. The genetic focus of the KORA studies is laid on the participation of inflammatory genes on type 2 diabetes and the metabolic syndrome as well as on the validation of already known candidate genes in this huge population-based pool of subjects.

\section{Acknowledgements}

The KORA research platform (KORA: Cooperative Research in the Region of Augsburg) was initiated and funded by the GSF - National Research Centre for Environment and Health, which is funded by the German Federal Ministry of Education, Science, Research and Technology and by the State of Bavaria. This work was supported by grants from the German National Genome Research Net (NGFN) given to the genotyping platform Munich as well as by the Deutsche Forschungsgemeinschaft, the European Foundation for the Study of Diabetes, the Federal Ministry of Health, the Ministry of Science and Research of North RhineWestphalia and the Department of Internal Medicine II-Cardiology at the University of Ulm.

We thank Michaela Bunge and Petra Weskamp for excellent technical assistance. The genetic part of the work was performed in the "Genome Analysis Centre (GAC)" of the GSF - National Research Centre for Environment and Health.

\section{Funding}

The investigations on diabetes in MONICA/KORA have been supported by GSF, DDZ-Deutsches Diabeteszentrum, BMBF Federal Ministry of Education and Research (FKZ 01ER 9502/0, 01GS0423), DFG - Deutsche Forschungsgemeinschaft (TH 784/ 2-1, Wi 621/9-1) and NGFN - Nationales Genomforschungsnetz (01GS0485).

\section{Reference}

${ }^{1}$ Rathmann W, Haastert B, Icks A et al. High prevalence of undiagnosed diabetes mellitus in Southern Germany: Target populations for efficient screening. The KORA survey 2000. Diabetologia 2003; 46: $182-$ 189

2 Illig T, Bongardt F, Schöpfer A et al. Significant association of the interleukin-6 gene polymorphisms C-174G and A-598G with type 2 diabetes. J Clin Endocr Metab 2004; 89: 5053 - 5058

${ }^{3}$ Müller S, Martin S, Koenig W et al. Impaired glucose tolerance is associated with increased serum concentrations of interleukin 6 and coregulated acute-phase proteins but not TNF-alpha or its receptors. Diabetologia 2002; 45: 805-812

${ }^{4}$ Pradhan AD, Manson JE, Rifai $\mathrm{N}$ et al. C-reactive protein, interleukin-6, and risk of developing type 2 diabetes mellitus. JAMA 2001; 286: $327-334$

${ }^{5}$ Fishman D, Faulds G, Jeffery R et al. The effect of novel polymorphisms in the interleukin-6 (IL-6) gene on IL-6 transcription and plasma IL-6 levels, and an association with systemic-onset juvenile chronic arthritis. J Clin Invest 1998; 102: 1369-1376

${ }^{6}$ Terry CF, Loukaci V, Green FR. Cooperative influence of genetic polymorphisms on interleukin 6 transcriptional regulation. J Biol Chem 2000; 275: 18138 - 18144

${ }^{7}$ Fernández-Real JM, Broch M, Vendrell J et al. Interleukin-6 gene polymorphism and insulin sensitivity. Diabetes 2000; 49: 517-520

${ }^{8}$ Kubaszek A, Pihlajamäki J, Komarovski V et al. Promoter polymorphisms of the TNF $\alpha(\mathrm{G}-308 \mathrm{~A})$ and IL-6 (C-174G) genes predict the conversion from impaired glucose tolerance to type 2 diabetes. Diabetes 2003; 52: $1872-1876$

${ }^{9}$ Kubaszek A, Pihlajamäki J, Punnonen K et al. The C-174G promoter polymorphism of the IL- 6 gene affects energy expenditure and insulin sensitivity. Diabetes 2003; 52: 558 - 561

${ }^{10}$ Möhlig M, Boeing H, Spranger J et al. Body mass index and C-174G interleukin-6 promoter polymorphism interact in predicting type 2 diabetes. J Clin Endocrinol Metab 2004; 89: 1885- 1890

${ }^{11}$ Stephens JW, Hurel SJ, Cooper JA et al. A common functional variant in the interleukin- 6 gene is associated with increased body mass index in subjects with type 2 diabetes mellitus. Mol Genet Metab 2004; 82: $180-186$

${ }^{12}$ Vozarova B, Fernández-Real JM, Knowler WC et al. The interleukin-6 $(-174) \mathrm{G} / \mathrm{C}$ promoter polymorphism is associated with type 2 diabetes mellitus in Native Americans and Caucasians. Hum Genet 2003; 112: $409-413$

${ }^{13}$ Jones SA, Rose-John S. The role of soluble receptors in cytokine biology: the agonistic properties of the sIL-6R/IL-6 complex. Biochim Biophys Acta 2002; 1592: 251 -263

14 Brull DJ, Montgomery HE, Sanders J et al. Interleukin-6 gene - 174g>c and $-572 \mathrm{~g}>\mathrm{c}$ promoter polymorphisms are strong predictors of plasma inerleukin- 6 levels after coronary artery bypass surgery. Arterioscler Thromb Vasc Biol 2001; 21: 1458-1463

${ }^{15}$ Herder C, Bongardt F, Schöpfer A et al for the KORA Study Group. Association of the interleukin- 6 gene polymorphism C $-573 \mathrm{G}$ with circulating IL-6 concentrations and type 2 diabetes.(submitted)

${ }^{16}$ Illig T, Bongardt F, Schöpfer A et al. The endotoxin receptor TLR 4 polymorphism is not associated with diabetes or components of the metabolic syndrome. Diabetes 2003; 52: 2861 - 2864

17 Weedon M, Schwarz P, Horikawa Yet al. Meta-analysis confirms a role for Calpain-10 variation in type 2 diabetes susceptibility. Am J Hum Gen 2003; 73: $1208-1212$

${ }^{18}$ Löwel H, Döring A, Schneider A et al. The MONICA Augsburg surveys Basis for prospective cohort studies. Gesundheitswesen 2005; 67 S1: $\mathrm{S} 13-\mathrm{S} 18$

${ }^{19}$ Holle R, Happich M, Löwel H et al. KORA - A research platform for population based health research. Gesundheitswesen 2005; 67 S1: S19-25

${ }^{20}$ Wichmann HE, Gieger C, Illig T. KORA-gen: Resource for population genetics, controls and a broad spectrum of disease phenotypes. Gesundheitswesen 2005; 67 S1: S26-S31 
${ }^{21}$ Löwel H, Meisinger C, Heier M et al. The population-based Acute Myocardial Infarction (AMI) Registry of the MONICA/KORA study region of Augsburg. Gesundheitswesen 2005; 67 S1: S31 - S37

22 Döring A, Meisinger C, Thorand B et al. Ernährungsverhalten und Übergewicht: Untersuchungen in den MONICA/KORA-Studien. Gesundheitswesen 2005; 67 S1: S51 -S56

${ }^{23}$ Thorand B, Schneider A, Baumert J et al. Case-Cohort study 19842002. Fall-Kohorten-Studien: Ein effektives Design zur Untersuchung von Biomarkern als Risikofaktoren für chronische Krankheiten - Darstellung am Beispiel der MONICA/KORA Augsburg Fall-Kohorten Studie 1984-2002. Gesundheitswesen 2005; 67 S1: S98 -S102

${ }^{24}$ Meisinger C, Döring A, Heier M et al. Type 2 Diabetes mellitus in Augsburg - an epidemiological overview. Gesundheitswesen 2005; 67 S1: S103-S109

${ }^{25}$ Rathmann W, Haastert B, Icks A et al. The Diabetes Epidemic in the Elderly Population in Western Europe: Data from Population-Based Studies. Gesundheitswesen 2005; 67 S1: S110-S114 